Gabriel Hasík: ${ }^{1}$

\title{
Middle class: ways of defining and the special case of China ${ }^{2}$
}

Many ways of classifying the middle class more or less reflect the level of local prices, historical background or social aspects. The middle class is generally considered one of the main pillars of the market economy without which achieving and maintaining political stability would be impossible. This is based on the assumption that middle-class members prefer rational political decisions, reject political extremism and prefer political compromise. At the same time, however, the middle class has rising expectations and can therefore be a significant factor in political change. The Chinese middle class has one distinct difference over Western countries. While the middle class in the Western countries is the enemy of the regime and the trigger for democratization, the Chinese middle class has often very close relations with the ruling party. This article aims to show the major approaches to define the middle class, respectively, the deeper sociological meaning of the class in general and specifically in China. The article is based on literary research, and apart from theoretical part defining middle class, it describes challenges Chinese middle class is facing. The main contribution of the article is the clear description of the theoretical concept of the middle class and the identification of differentiating factors and determinants of the Chinese middle class.

\section{Introduction}

There are many ways of classifying a middle class, which more or less reflect the level of local prices, historical background or social aspects. The middle class is generally considered to be one of the main pillars of the market economy without which achieving and maintaining political stability would be impossible. This is based on the assumption that middle-class members prefer rational political decisions, reject political extremism and prefer political compromise. At the same time, however, the middle class has rising expectations and can therefore be a significant factor in political change. With its rising income, middle class requires higher quality of education, better healthcare or cleaner environment. The Chinese middle class has one distinct difference over Western countries. While the middle class in the Western countries is the enemy of the regime and the trigger for democratization, the Chinese middle class has often very close relations with the ruling party. Many entrepreneurs are members of, or close to, the party that has often helped them to gain their actual wealth. An Chen, a Chinese professor of political science with American education, has defined, for example, in middle class members the so-called "elitist complex," for which they have the psychological barrier to accept the notion that every person's voice is equally important. From this point of view, the Chinese middle class looks like the one that would protect the regime against the process of any democratization in China. On the contrary, the driving force could become working class. Working class is generally the poorest, and among social classes, it is the least satisfied either because of income or because of inaccessible better education or health care.

The term middle class, despite differing definitions, makes us always think about approximately the same group of people. However, the view that we have is the Western view, and we expect from the middle

\footnotetext{
${ }^{1}$ University of Economics, Prague, Faculty of International Relations (gabriel.hasik@vse.cz).

2 This article was written within the project IGA VŠE Prague no. F2/47/2016 "Influence of a growing global middle class on selected developing and developed regions'.

DOI: 10.14267/RETP2021.02.08
} 
class to have similar global features. This article addresses the whole range of approaches to the middle class, but at the same time, it also brings a new, different approach that does not match our ideas and expectations of the middle class. It is China's approach to this social stratum. Due to its size and importance, it cannot be ignored. The variations that are described in this article can ultimately contribute to changing the middle class view, as we know it until now.

\section{Concept and classification of middle class}

The simplified middle class definition says that, the middle class is a social group that is located between the higher and the working class. According to the Cambridge dictionary, the middle class is a social group that consists of well-educated people, such as doctors, lawyers, or teachers who have a good job. They are neither very rich nor very poor. However, there are many other ways of classifying the middle class, which define it based on different criteria. In the Western society, there are two basic approaches, based on which the middle class is defined as a separate sociopolitical group.

- Objective approach

○ Quantitative branch

○ Qualitative branch

- Other approaches

- Number of politically active population

○ Number of entrepreneurs

- Level of human development and savings

○ Consumption

- Number of registered cars

- Socioeconomic group classification based on user features (Facebook)

\section{Subjective approach}

According to the first, subjective approach, belonging to the middle class is based on the self-empathy of an individual. The origin of the subjective approach is attributed to Aristotle, according to who belonging to the social class does not depend on the physical characteristics of an individual, income or property, but on the contrary, it depends on how individuals perceive themselves [Eulau, 1956]. According to the forerunner of the modern subjective approach to class measurement, Richard Centers, social classes are psychological clusters that depend only on the individual members' awareness that they belong to that specific class. According to Centers, the boundaries between classes are, in addition, markedly different from those defined by sociologists who hold the objective approach [Centers et al., 1998]. In addition, according to this approach, the strong psychological relevance of middle-class individuals also has a significant impact on political behavior and attitudes. Empirical research on pro-democratic political attitudes from the University of Cambridge has shown that individuals who have been subjectively regarded as middle class members have achieved a better survey result than workers in the working class have [Walsh, Jennings and Stoker, 2004].

\section{Objective approach}

The second, objective approach claims that the sociopolitical class is primarily defined by some major socio-economic factors. These factors include income, education, and occupation. This approach distinguishes between two conceptual branches; the first quantitative branch emphasizes the importance 
of the quantitative qualities of the above-mentioned factors (income, education, profession ...). According to this branch, the best way to determine belonging to a given class is to create a quantitative index of income, education, and occupation and, based on a rank in the index, to determine the belonging of the individual to the right class. Based on this division, the middle class is achieving intermediate values. However, this division can be interpreted also differently, for example, according to Lister Milbrath, a political science professor, those who achieve high values for all the three parameters examined, should belong to a higher class, those who achieve high values in two parameters, should belong to a middleclass and so on [Milbrath and Goel, 1977]. Norman Nie with his colleagues took a similar approach in 1969, when they passed a comparative study of five nations (USA, Great Britain, Germany, Italy and Mexico). They set up a similar index to Lester Milbrath, but each variable was assigned a different weight. They situated the middle class within the second third of the index. Based on this scale, they found that up to half of the US population was belonging to the middle class in the 1970s, compared to Mexico, with the share of only 16\% [Nie, Powell and Prewitt, 1969].

The second, qualitative branch of the objective approach emphasizes the importance of the qualitative parameters of the mentioned factors. This branch defines middle class members based on specific socioeconomic characteristics that distinguish them qualitatively from members of other classes. One of the most frequently used qualitative approach scale is neo-Marxist scale developed by Erik Olin Wright. His scale includes three subcategories, which define the main categories: means of production, level of authority (based on managerial experience) and expertise. Under the first sub-category, those who own the means of production are managers as owners. Owners are divided into two categories: the bourgeoisie and the small bourgeoisie, based on the size of the means of production they own. Under the second subcategory, those who supervise other workers are managers. The third subcategory contains experts with expertise. The rest of the society is divided among workers, farmers and the unemployed. The middle class includes small bourgeoisie, managers and experts [Wright, 2000].

The well-known German sociologist Max Weber, who lived at the turn of the 19th and 20th centuries, also used objective approach. According to division of social classes by Max Weber, the elite or higher class represents $1 \%$ of the society [Wright, 2007]. This $1 \%$ has control over financial capital; its members occupy key positions in politics, culture and education, including owners and senior managers of large companies. The middle class can be divided into 3 groups, the old middle class, which includes entrepreneurs and owners of small companies, a higher middle class where we include educated professionals equipped with very high social capital, doctors, lawyers, intellectuals and architects. These people are often local leaders, influencing their surroundings, and often able to live on their own, not necessarily needing an employment. The third middle-class group is a lower middle class. They are teachers, social workers, nurses, nurses and officials. Unlike the upper middle class, these people are forced by the nature of their job to work as employees; they cannot work on their own account. They are therefore more dependent on their employers and do not have much choice. Below the lower middle class, according to Max Weber, the working class exists. Outside the individual classes are unemployed people without work and income who are dependent on social benefits and state support. This characteristic is suitable for understanding the basic distribution of social classes, according to the most frequently occurring characteristics, but it is unusable to define the specific size of individual groups. In China, which sees the enormous growth of the middle class, words like middle class, middle stratum, or middleincome stratum, were still not used for ideological reasons ten years ago [Li, 2010]. 
The middle class, however, has, apart from purely statistical significance, another historical one. Since the end of the 14th century, when the middle class came from the bourgeoisie, it was an important part of the society that has made it possible to strengthen capitalism and trade between nations. The middle class was generally considered a source of innovation and entrepreneurship and widely regarded as one of the main pillars of the market economy without which achieving and maintaining political stability would be impossible. This is based on the assumption that middle-class members prefer rational political decisions, reject political extremism and prefer political compromise.

According to John Maynard Keynes, market demand must be sufficient to cover the output of the industry, which is relying on new investments. Investments support economic growth and consumption must grow as well [Keynes and Krugman, 2011]. According to him, companies with unequally distributed wealth who do not have a strong middle class consume less and are unable to build a modern economy. The rich layer saves more than average and has lower consumption compared to the size of his property. From this, it can be deduced that if the income for most people is stagnant or falling, there is not enough market demand to motivate companies to invest. However, debt investments cannot last indefinitely. When a break in the number of new loans taken occurs, often during the economic crises, the economy falls in recession and is sparked for many years.

Another characteristic of the middle class, apart from relatively constant and high consumption, is the high level of trust. If a society is largely a middle class, people who doesn't know each other are more willing to try a joint venture, more optimistic, and believe they are a strong group. It is this human trait, the ability of trust that has long been considered important in economic growth as well [Mill, 2000]. According to the 2010 study, a 10\% increase in confidence brings a $0.5 \%$ increase in GDP growth over the next five years [Dincer and Uslaner, 2007].

The strong middle class, in addition to its positive impact on the growth of consumption and the positive effects of high confidence within the group, also influences state governance. As the middle class is generally more involved in public affairs, it has an interest in respecting the rules, avoids conflicts, is not easy to manipulate, and seeks to promote publicly beneficial laws contributing to better public administration. On the contrary, in the case of economic inequality and the weak middle class, the political system is unbalanced and discourages the political participation of the poor. According to another study, which was conducted in 2008 and studied developed countries, when economical imbalance grows importantly, a $13 \%$ drop in people's participation in the election occurs and a political debate declines by $12 \%$ [Solt, 2008].

Being a middle class member in a society where the middle class prevails, where people have enough finance and stability but cannot afford to go to early retirement, contributes to building a healthy capitalist system. Parents often teach their children the same way as they were learning, to respect work and education, because they probably will not live on capital gains either.

For example, Samuel Huntington rejects that the market economy itself and the development of capitalism are enough to direct the state to political democracy. According to him, historical and situational factors are also important. The middle class is characterized as revolutionary in its beginnings, but over time, it becomes more and more conservative. Seymour Martin Lipset, on the other hand, sees a well-educated middle class, politically moderate and economically self-sufficient as an important presumption of a possible re-education in a democracy [Li, 2010]. 
The middle class also has a positive impact on education itself. In schools where the majority of middleclass pupils study, lower-class pupils also get better results and have more successful careers. As I will recall later in this work, linking the middle class and entrepreneurs is one of the important links. According to the Kauffman Organization and the survey which was organized by the 549 founders of American companies from different industries in 2009 , up to $72 \%$ of entrepreneurs come from the middle class, which again confirms that the middle class has a positive effect on the development of capitalism [Wadhwa et al., 2009].

For a long time, one's own housing was also considered one of the middle class features. In this case, however, as with the redistribution of public resources, it has been shown that a strong middle class cannot be created by social engineering. These efforts to create a large group of real estate owners, when US banks were put under political pressure to give loans to people from the lowest groups, was one of the launchers of the 2008 Mortgage Crisis [Durguner, 2012].

Now, when assessing the middle class, the increasing weight is attributed to consumption, compared to education or employment, as it has been so far. The middle class is currently characterized by so-called "new consumerism". It is a constant effort by today's society to increase demands for lifestyle standards, originality, imaginativeness, attractiveness of brands used, but also the growing gap between real revenues and expenditures [Kharas, 2010]. Overall, it could be said that the middle class consumer is willing to pay for better quality and originality in order to be distinguished. This trend, as already mentioned above, also supports investment growth by encouraging manufacturers to continuously innovate and produce diverse products.

The importance of the middle class is also attributed to the enormous growth in international trade that occurred in the 21st century. While the US and European middle class are the source of world demand, the poor Asian countries are satisfying it. This trend has also created a paradox where poor countries have grown significantly without the local middle class. In spite of the historical experience, in this case the lower labor class took over the role of the middle class and with the help of the government managed to benefit from international trade [Kharas, 2010].

\section{Other approaches}

In middle class definitions, however, there are many other approaches. The most commonly used approaches to defining a middle class include those evaluating it based on the following parameters:

- Number of politically active population

- Number of entrepreneurs

- Level of human development and savings

- Consumption

- Number of registered cars

- Socioeconomic group classification based on user features [Facebook]

The first approach deduces the number of middle class members according to the number of politically active population. According to it, there is a strong link between democracy and middle class. Democracy is generally associated with growth, free market and prosperity, and it follows from this approach that the middle class is involved in economic growth. However, in order for democracy to exist, strong active political participation is needed for the public. It is precisely the interest of the middle class to take 
political action that determines by an approximate estimate the size of the middle class [Banerjee and Duflo, 2007].

The second approach determines the size of the middle class according to the number of entrepreneurs. This approach is based on the tradition of defining middle class based on its occupation, distinguishing it from peasants and nobility who represented the feudal economy [Acemoglu and Zilibotti, 1997]. However, this approach is contradicted by several studies, according to which at present the average middle-class member is not an entrepreneur or only an owner of a small company with low turnover and low profit. In addition, in the majority of developed countries, there is an abundance of entrepreneurs compared to the relatively large middle class [Banerjee and Duflo, 2007].

The third approach defines a middle class based on education and ability to make savings. It is because parents who became middle class form their children according to their current economic situation and try to direct them to get good education. Comparing to the higher class, which often relies only on income from renting capital, middle-class families lead their children to activities that require effort, determination, patience, and working ethics [Doepke and Zilibotti, 2007]. However, according to opponents, the middle class is of little importance as regards its contribution to the development of human capital. According to them, the pace of accumulation of human capital depends on the point from which it begins. Similarly, it is the ability to save. In the example of China, it is obvious that even people in the working class are able to save a large part of their income.

The fourth approach, which is currently used most frequently, determines the size of the middle class based on its consumption. Although the middle class is more a sociological than economic classification, consumption is better measurable and easier to grasp. According to this approach, the middle class can be defined in relative or absolute numbers. In relative terms, median household income or percentile is used. Median approach defines middle-income households by income between $75 \%$ and $125 \%$ of median household income [Birdsall, Graham and Pettinato, 2001]. When defining the middle class by percentile, the middle class includes households whose consumption is between the 20th and 80th percentiles. Relative definition of the middle class also has its disadvantages. Since each country has a different median, the definition of the middle class is different in each country and almost incomparable in absolute numbers.

Fifth approach, which is used to derive the middle class size is The Car Index. This is a different approach, which is used by the Carnegie Endowment for International Peace, and uses estimates of the number of passenger cars that are in use in the developing country. This is not a straightforward definition based on household consumption, but derived from it and, moreover, even easier to see, as there is a vehicle register in most countries. While the middle class can be defined in many different ways, defining it according to the ownership of a car is a rather interesting approach, which, compared to other approaches, reflects at the same time the relations in society. Owning a car is a financially demanding item, and from this point of view it can be said that the family belongs to the middle class. Compared to developed countries in which almost every household owns a car, in the developing countries ownership of the car means relative prosperity. In addition, the number of cars, as mentioned above, is easily traceable and credible based on mandatory registration. Another advantage of this approach is that car owners have to pay fees regularly, so that they can also see the potential drop of cars and the derived middle class. At first glance, it might seem that other appliances commonly purchased by households could replace the car ownership but the car in these countries is a symbol of prosperity and social status. 
Assumption that one household would buy more cars can be considered relatively unlikely and statistically insignificant, as even in the G20 there is only a small percentage of households that own more than one car. This makes it possible to assume that there will be even less of more-than-one-carhouseholds in the developing countries. According to the World Bank study, in 2009 more than 1 car in developing countries owned only $1 \%$ of the households, compared to five percent in developed countries. Even in these few cases, it can be assumed that many of these cars are used for business, for example as a taxi.

The last, sixth approach is an online system that uses classifiers to predict the socioeconomic group of users of the online system, in this case Facebook. The classifiers use models that are trained using features based on global information about a population of users such as demographic information, device ownership, internet usage, household data, and socioeconomic status. The global information can be aggregated from market research questionnaires and provided to the online system. The classifiers input information about a user and output a probability that the user belongs to a given socioeconomic group. The input information is based on a user profile on the online system associated with the user as well as actions performed by the user on the online system. Thus, the online system can predict the user's socioeconomic group without using the user's income information. The online system can generate content for presentation to the user based on the predicted socioeconomic group [United States Patent Application, 2018].

\section{Chinese middle class}

According to the Chinese Communist ideology that emerges from Marxism, the middle class is not a legitimate or separate social class. Even in 1990, under the pro-reform regime of Teng Siao Pching, the middle-class public debate was banned and the middle class was labeled as the product of capitalist states. It seemed that the middle class would never exist in China at all. Even Teng's market reforms implied the emergence of three new layers within the private sector, including, but not limited to, private entrepreneurs and business owners. However, these two layers along with the intellectuals were not be considered as a separate class, but as part of the working class. On the other hand, high-level managers were shifting between the monopolistic capitalist layer and the upper middle class.

In general, the term "middle class" was a taboo in the 1990s in China, and the newly emerging groups of entrepreneurs, private employees and intellectuals were not considered a single, specific group. Only middle-income urban families and some interest groups were counted as so-called "middle layer". In any case, these new groups were outside the state or public sector, and they were called "early rich groups". Early rich groups were considered a part of privileged higher levels, in the emerging "unequal and unstable" dual social system. In this respect, therefore, China still lacked a full-fledged middle class.

The situation has begun to change slowly since 2000 when the central government decided to classify new layers. In "Classroom classifications in contemporary China" publication, published by the Central Party School of the Communist Party of China, the individual newly formed groups were described as separate layers compared to the previous trend of joining them to a common class [Qiang, 2016]. The greatest progress in perceiving social classes in Chinese government regime occurred only in 2002 when Chinese sociologists published a book on social strata in modern-day China called the "Social Class Review in modern China" [Lu, 2012]. 
This publication recognized 10 social strata:

- State and private executives

- Managers

- Experts

- Owners of private companies

- Administrative staff

- Small business owners

- Staff in shops and services

- Industrial workers

- Workers in agriculture

- Unemployed

Authors in this publication also used terms "higher, medium higher, medium medium, medium lower, and lower" to classify the 10 layers in the five existing categories. Although this book still did not define the official definition of the middle class, it contained an analysis of so-called middle layer, which listed almost all the newly formed groups of the population that moved in the private sphere.

Since the publication of this book, the public perceived the middle class in a very positive way; even it was attributed significant tasks, e.g. ensuring the coordination, stability and order required by a modern society. In addition, the middle class should be a model for maintaining positive social values, working motivation, respect for the rule of law, creativity, or openness to new things. Compared to the past, the middle class was no longer condemned for increasing income and increasing social inequalities in society, but rather as an intermediary between the poor and the rich. Almost since 2005, the rise in the middle class did not represent an enemy to the political regime, but rather the opposite. Years of open discussion about social classes helped to put an end to the orthodox Chinese communistic approach to new classes [Li, 2010].

Currently, the middle class of China is considered a firm component of society, and the Communist regime is interested in its growth comparing to the 1990s. As early as 2011, the Chinese middle class was the second largest in the world, with 157 million people. In proportion to the size of the Chinese population, it is only $12 \%$, but with the projected increase, the Chinese middle class would represent up to $70 \%$ of the entire Chinese population by 2030, gaining a head start in the middle class ratio to the entire population [Rakesh, 2015].

\section{Chinese definition of middle class}

Classification of the population into the middle class is complicated. As it can be seen from this article, there are many approaches to define middle class. Widely used is the classification based on economic factors such as income or consumption. However, the approach that is used in China is different and more complex. Higher civic awareness and literacy also belong to the middle class specifics. In income-based classification, however, an important part of university-educated Chinese population could be outside. However, academically educated people are a very important part of society, and they are often important social influencer. That is why it is important for the Chinese government to include this educated group in statistics and keep it under the supervision of the authorities. In general, four criteria are used in defining middle class in China. The first is income that should be reasonably high and stable. The second criterion is employment. A middle-class member should have a professional or managerial position. The third 
criterion is education, and the fourth is consumption. The middle class can afford larger houses, luxury cars and other expensive products [Michael Hsiao, 2015].

The middle class in China has a specific economic and political significance for society as opposed to other countries. We can further divide it into other subgroups, e.g. new middle class (specialists and managers), old middle class (small business), marginal middle class and private entrepreneurs. In general, private entrepreneurs are considered members of a higher social stratum, but in the case of China as they have emerged recently, we consider them to be part of the middle class. In China, senior civil servants and directors of state-owned enterprises are considered to be higher social class members. The development in time of the middle class as defined above is shown in the following table.

Table 1 | Growth rate of different Chinese social classes [1982 - 2006]

\begin{tabular}{|l|c|c|c|c|c|}
\hline Year & $\begin{array}{c}\text { Capitalist } \\
\text { class }\end{array}$ & $\begin{array}{c}\text { New middle } \\
\text { class }\end{array}$ & $\begin{array}{c}\text { Old middle } \\
\text { class }\end{array}$ & $\begin{array}{c}\text { Marginal } \\
\text { middle class }\end{array}$ & $\begin{array}{c}\text { Working } \\
\text { class }\end{array}$ \\
\hline $\mathbf{1 9 8 2}$ & 0.0 & 13.9 & 0.1 & 19.7 & 66.3 \\
\hline $\mathbf{1 9 8 8}$ & 0.1 & 17.2 & 3.2 & 23.8 & 55.7 \\
\hline $\mathbf{1 9 9 0}$ & 0.5 & 19.6 & 2.2 & 19.9 & 57.8 \\
\hline $\mathbf{1 9 9 5}$ & 0.6 & 22.1 & 5.5 & 26.6 & 45.2 \\
\hline $\mathbf{2 0 0 1}$ & 1.5 & 16.6 & 10.3 & 33.2 & 38.4 \\
\hline $\mathbf{2 0 0 2}$ & 1.1 & 23.6 & 11.1 & 29.1 & 35.1 \\
\hline $\mathbf{2 0 0 5}$ & 1.6 & 21.0 & 9.7 & 31.4 & 36.3 \\
\hline $\mathbf{2 0 0 6}$ & 0.6 & 18.8 & 9.6 & 25.4 & 35.7 \\
\hline
\end{tabular}

Source: [Michael Hsiao, 2015]

From 1982 to 2006, the new middle class grew by about 10 percent. The old middle class, which almost did not exist in 1982 and contains small entrepreneurs, represented almost 20 percent of population in 2006. In Western countries, the share of the new middle class is growing at the expense of the old one, comparing to China, where both groups are growing at the same time. While the old middle class prevails in smaller and middle cities, the new middle class is growing in larger cities. The report clearly shows a rapid increase in the middle class, at the expense of the working class. In 2006, more than $60 \%$ of the population belonged to the middle class based on the specific Chinese definition of social classes. The middle class in China was developing during significant institutional changes. The country went from the planned to the market economy. Until the market reforms in the 1970s, most of the employees worked in the state sector and the middle class or capitalists almost did not exist. In the upcoming period, there was room for the emergence of capitalists or the old middle class in the private sector. At the same time, the new and marginal middle class moved to the private sector. Surprisingly, however, more than $60 \%$ of the new middle class or 54\% of the marginal middle class remain in the public sector [Michael Hsiao, 2015]. This fact explains one of the characteristics of the Chinese middle class - its members have a close relationship with the state and are dependent on its socio-economic policy. The middle class is generally considered a sociopolitical force of change in society. In China, this is a matter for researchers, but there are two views on it. One group believes that the middle class is a propagator of democratization, while the latter group believes that the Chinese middle class has a conservative political stance and, on the contrary, is a major force in maintaining the current political system in power. This second group argues that the middle class is the largest beneficiary of the benefits of economic reforms and growth. As a result, they are trying to maintain the current undemocratic system. The second reason why a pro-democracy 
stance cannot be expected from a middle class is that a large part of them is working in the government sector, or they work as experts or managers for the government. Even because of this close relationship, the middle class prefers a strong and stable government and is not expected to promote the democratization of society. However, the view on the democratization of society is also different within the middle class itself. Here is important the division into the four mentioned subgroups, as the new middle class and the marginal middle class hold more democratic positions than the old middle class and capitalists who have greater respect for government authority. On the other hand, members of these two subgroups also have a considerable degree of respect for state authority, which suggests that the Chinese middle class as a whole is rather on the side of the Chinese government. Despite the sympathy with democracy, the middle class generally agrees that the current political and economic situation is the most appropriate for present-day China. In addition, important part of the society agrees that China is moving towards a more democratic system. However, in order to implement a more democratic arrangement, higher education and economic or social progress are needed.

\section{Social Challenges of the Chinese Middle Class}

With the growing middle class, besides the positive impact on society, both the growth of well-being and the standard of living have negative externalities. High consumption of the middle class has a negative impact on the environment. The growing number of new car registrations, rising fuel consumption and urban growth, result in high CO2 emissions and environmental pollution. In the year 2015, 1.1 million people died due to the air pollution in China. [ChinaPower Project, 2018] Together with India, which has achieved similar scores, it is about half of deaths for this reason globally [Reuters, 2018a]. According to University of California at Berkeley, air pollution causes nearly 4,000 premature deaths a day [the Guardian, 2018]. For China, and predominantly the middle class, which is the driving force behind the economic development of the country, is a matter of priorities. At present, the country is struggling to fight global climate change, but domestic situation is only slowly improving.

Another challenge for the Chinese middle class is the increasing consumption of proteins. Meat, which has long been considered luxury good and has been sporadically in the diet, is becoming a regular part of the diet. Growing intensive livestock farming also has a negative impact on the environment. According to the Food and Agriculture Organization [FAO] of the United Nations, the share of the undernourished population fell from $23.9 \%$ in 1990 to $9.3 \%$ in 2015 . However, with decreasing malnutrition, meat consumption increased from about 7 million tons in 1975 to 75 million tons in 2017 [OECD, 2018]. The growing middle class also significantly contributes to the demand for better food. After several scandals linked to food quality, their import grew between 2005 and 2015 from \$ 6 million to \$ 300 million [ChinaPower Project, 2018].

The change in middle-class eating habits and the increased share of sedentary work occupations in this class also contributes to an increase in the cost of health care. China is currently experiencing a significant increase in the number of patients with chronic and complicated diseases such as cancer and diabetes, which are mostly found in Western countries, and their treatment is lengthy and costly. Between 2004 and 2014, health care costs grew by almost 400\% [Reuters, 2018b]. By 2025, the annual cost is expected to quadruple to $\$ 1.9$ trillion. The accelerated aging of Chinese society also supports this negative expectation. The Chinese demographic pyramid is gradually changing, and the dependency ratio is expected to change from $36.6 \%$ in 2015 to $69.7 \%$ in 2050 [ChinaPower Project, 2018]. Without growing retirement age, which will predominantly hit the middle class, the social system will not be sustainable. 
China's economic growth is also rising income inequality. The value of the Gini coefficient has almost doubled from 0.28 to 0.55 in 2015 since the 1980s. This ratio is so higher than in the US or Japan [Xie and Zhou, 2014]. This fact also shows how general middle class growth at the same time does not mean the same economic benefit for the whole group.

Last but not least, the challenge faced by China and linked to the growing middle class is the rising costs of the social system. For example, between 2006 and 2015, social support increased by $275 \%$. Additionally, healthcare was extended for the unemployed and minimum wages increased in fourteen provinces and larger cities [Xinhuanet.com, 2018].

\section{International approach to the Chinese middle class}

Determining the size of the middle class is very complicated as mentioned above and depends on the chosen approach and method. In the previous chapter, a specific way of defining middle class was presented. It was Chinese society and government point of view. However, the middle class as a social group is a global phenomenon that is being studied and common parameters are needed to compare this class across multiple countries.

Table 2 Size of middle class in China according to different institutions

\begin{tabular}{|l|c|c|}
\hline Institution & Middle class definition & Estimated size [mil.] \\
\hline Pew & $\begin{array}{c}10,01-20 \$ \\
\text { [consumption/person/day] }\end{array}$ & 235 [2011] \\
\hline McKinsey & $\begin{array}{c}60000-229000 \text { RMB [household } \\
\text { income/year] }\end{array}$ & $460[2012]$ \\
\hline Credit Suisse & $50000-500000 \$$ [personal property] & $109[2015]$ \\
\hline Ernst \& Young & $10-100 \$$ [person/day] & $150[2010]$ \\
\hline Goldman Sachs & $16-82 \$$ [person/day] & $149[2013]$ \\
\hline
\end{tabular}

Defining a middle class in absolute numbers is comparatively more complicated, and almost every organization or bank has its own scale. Many economists have long used the World Bank scale, which defined a middle-income class in the range of $\$ 2$ to $\$ 13$, at PPP prices of 2005. Economists generally recognized the two-dollar barrier as the poverty line, and anyone who had a daily income higher than these 2 dollars was out of the danger. Thirteen dollars was the poverty line in the US in 2005 , so this middle class determination responds to developing countries, but not to the developed world [U.S. Department of Health \& Human Services, 2018]. Practically speaking, however, there are two distinct middle classes, one that is a middle class according to any standards, global middle class, and the second, much larger, which is a middle class according to the standards of the developing world.

According to the World Bank classification and 2005 figures, the world middle class was of 2.6 billion people, which was double the number compared to 1990. Only in China, for example, the middle class has grown over the past 15 years from 174 million people to incredible 806 million. For India, it was an increase from 147 million to 264 million [Skolkovo.ru, 2018]. However, if we used a different middleclass assessment introduced by Homi Kharas, the former World Bank's chief economist, currently working at The Brookings Institution, within their middle class range (\$10-100), 1.8 billion people in the world would belong to the middle class. This is up to $60 \%$ in developed countries and $20 \%$ in BRIC countries [Kharas, 2018]. 
The Pew Research Center (Pew) also uses a different definition of the middle class based on consumption. It divides the population in each country into 5 groups, based on daily consumption or household income, on a poor, low-income, middle-income, upper-middle-income and high-income group. The first group, the poor, is bordered by a 2-dollar income that is a poverty line, similar to the World Bank. The second, low-income group has revenues in the range of 2 to 10 USD. 10-dollar limit is, according to Pew, the limit when we can talk about the middle class. Unlike the World Bank, which also considered the middle class households with two-dollar consumption.

Both the World Bank, OECD and the private sector are gradually accepting the 10-dollar threshold introduced by Pew. This limit, which is five times the poverty line, is also considered a safe income that does not threaten to fall back into poverty. Other well-known middle class definitions include Goldman Sachs, which defines it for revenue ranging from $\$ 6000$ to $\$ 30,000$ a year and consultancy company McKinsey speaks of a middle class with a household income between \$ 9,000 and \$ 34,000 [McKinsey \& Company, 2018].

\section{Conclusion}

The article presents different approaches to defining a middle class. The middle class is, according to the simplest definition, the class between the working and the upper class. Compared to the working class, its members have income that allows them to devote themselves to leisure activities and to be interested in political situation. On the contrary, they do not have enough income to ignore public life and live in their carefree world. The middle class is generally attributed to important societal tasks, as is clear from this article, however in the case of China it can be at least argued.

The article gradually defines the different approaches by which we identify the middle class. According to the first, subjective approach, belonging to the middle class is based on the self-empathy of an individual. A second, objective approach claims that this sociopolitical class is primarily defined by some major socio-economic factors. These factors include income, education, and occupation. This approach distinguishes between two conceptual branches; the first emphasizes the importance of the quantitative qualities of the above-mentioned factors (income, education, profession ...). According to this quantitative branch, the best way to determine belonging to a given class is to create a quantitative index of income, education, and occupation and, based on a rank in the index, to determine the belonging of the individual to the correct class. The second, qualitative branch of the objective approach underlines the importance of the qualitative characteristics of the mentioned factors. This branch defines middle class members based on specific socio-economic characteristics that distinguish them qualitatively from members of other classes.

In the final part, the article also presents a specific Chinese approach to the middle class phenomenon and, in brief, it mentions the common problems associated with the growth of this social class in China. For a comparison of middle class in China with other countries, the last chapter is dedicated to defining its size according to different approaches. The middle class in China, as shown by the article, is a term that has been banned for a long time and has only begun to be publicly used in recent years. This also explains the limited amount of resources from which it is possible to elaborate the scientific work. In any case, there is an increasing number of scientists and professionals in China; therefore, we can assume that the availability of relevant resources will increase. 


\section{References:}

Acemoglu, D.- Zilibotti, F. (1997): Was Prometheus Unbound by Chance? Risk, Diversification, and Growth. Journal of Political Economy, 105[4], pp.709-751. (online) Available at: http://www.econ.nyu.edu/user/debraj/Courses/Readings/AcemogluZilibotti.pdf Accessed 27 Feb. 2018.

Banerjee, A. and Duflo, E. (2007): What is Middle Class About the Middle Classes Around the World?. SSRN Electronic Journal. (online) Available at: http://economics.mit.edu/files/2081 Accessed 27 Feb. 2018.

Birdsall, N., Graham, C., Pettinato, S. (2000): Stuck in tunnel: Is globalization muddling the middle?

ChinaPower Project. (2018): Is air quality in China a social problem? (online) Available at: https://chinapower.csis.org/air-quality Accessed 27 Feb. 2018.

ChinaPower Project. (2018): How is China feeding its population of 1.4 billion? (online) Available at: https://chinapower.csis.org/china-food-security/ Accessed 27 Feb. 2018.

Dincer, O. and Uslaner, E. (2007): Trust and Growth. SSRN Electronic Journal. (online) Available at: http://www.jstor.org/stable/40541948?seq=1\#page_scan_tab_contents Accessed 27 Feb. 2018.

Doepke, M. and Zilibotti, F. (2007): Occupational Choice and the Spirit of Capitalism. SSRN Electronic Journal. (online) Available at: http://www.nber.org/papers/w12917.pdf Accessed 27 Feb. 2018.

Durguner, S. (2012): The 2007 Subprime Mortgage Crisis: Changing Characteristics of Lending to Subprime Households. SSRN Electronic Journal. (online) Available at: http://www.stat.unc.edu/faculty/cji/fys/2012/Subprime\%20mortgage\%20crisis.pdf Accessed 27 Feb. 2018.

Eulau, H. (1956): Identification with Class and Political Perspective. The Journal of Politics, 18[2], pp.232-253. (online) Available at: http://www.jstor.org/stable/2126983?seq=1\#page_scan_tab_contents Accessed 27 Feb. 2018 .

Guardian (2018): Air pollution in China is killing 4,000 people every day, a new study finds. (online) Available at: https://www.theguardian.com/world/2015/aug/14/air-pollution-in-china-is-killing-4000-people-every-daya-new-study-finds Accessed 27 Feb. 2018.

Hsiao, M. (2015): Chinese Trust Law: registration as the concept-substitution and a workout solution for investors (beneficiaries). Trusts \& Trustees, 21(8), 889-901.

Keynes, J. and Krugman, P. (2011): The general theory of employment, interest, and money. Houndmills, Basingstoke, Hamshire: Palgrave Macmillan. ISBN 1891396684

Kharas, H. (2010): The Emerging Middle Class in Developing Countries. Paris: OECD Publishing. (online) Available at:

https://www.researchgate.net/publication/46457345_The_Emerging_Middle_Class_in_Developing_Countries Accessed 27 Feb. 2018.

Kharas, G. (2018): The New Global Middle Class: A Cross-Over from West to East. (online) Brookings. Available at: https://www.brookings.edu/research/the-new-global-middle-class-a-cross-over-from-west-toeast/ Accessed 27 Feb. 2018.

Li, C. (2010): China's emerging middle class. Washington, D.C: Brookings Institution Press. (online) Brookings. ISBN 9780815704331.

Lu, X. (2012): Social structure of contemporary China. New Jersey etc.: World Scientific. ISBN 9789813238299.

McKinsey \& Company. (2018): Mapping China's middle class. (online) Available at: https://www.mckinsey.com/industries/retail/our-insights/mapping-chinas-middle-class Accessed 27 Feb. 2018.

Milbrath, L. and Goel, M. (1977): Political participation. Chicago: Rand McNally College Pub. Co. ISBN 05286-5095-5

Mill, J. (2000): Principles of Political Economy With Some of Their Applications to Social Philosophy, Vol II. Victoria: D. Appleton and Company. (online) Available at: http://www.econlib.org/library/Mill/mlP7.html Accessed 27 Feb. 2018. 
Nie, N., Powell, G. and Prewitt, K. (1969): Social Structure and Political Participation: Developmental Relationships, II. The American Political Science Review, 63[3], p.808. (online) Available at: http://www.econlib.org/library/Mill/mlP7.html Accessed 27 Feb. 2018.

OECD. (2018): Agricultural output - Meat consumption - OECD Data. (online) Available at: https://data.oecd.org/agroutput/meat-consumption.htm [Accessed 27 Feb. 2018].

Qiang, L. [2016]. Social Stratification in Contemporary China. Los Angeles: Bridge21 Publications. ISBN 1626430373.

Rakesh, K. (2015): A Global Middle Class Is More Promise than Reality. (online) Pewglobal.org. Available at: http://www.pewglobal.org/files/2015/07/Global-Middle-Class-Report_FINAL_7-8-15.pdf Accessed 27 Feb. 2018.

Reuters (2018a): China, India account for half world's pollution deaths in 2015: study. (online) Available at: https://www.reuters.com/article/us-china-pollution-health/china-india-account-for-half-worlds-pollutiondeaths-in-2015-study-idUSKBN15T0EO Accessed 27 Feb. 2018.

Reuters (2018b): China healthcare costs forcing patients into crippling debt. (online) Available at: https://www.reuters.com/article/us-china-healthcare-debt/china-healthcare-costs-forcing-patients-intocrippling-debt-idUSKCNOZQ03A Accessed 27 Feb. 2018.

Skolkovo.ru. (2018): SKOLKOVO Research - The Great Equalizer - The Rise of the Emerging Market Global Middle Class. (online) Available at: http://www.skolkovo.ru/public/ru/site_content/97-news-research/17252010-12-021564/ Accessed 27 Feb. 2018.

Solt, F. (2008): Economic Inequality and Democratic Political Engagement. American Journal of Political Science, 52[1], pp.48-60. (online) Available at: http://www.jstor.org/stable/25193796?seq=1\#page_scan_tab_contents Accessed 27 Feb. 2018.

Turner, B., North, C., Sorokin, P., Dollard, J., Davidson, P., Anderson, H., Sombart, W. and Centers, R. (1998): The early sociology of class. London: Routledge/Thoemmes Press. ISBN 0415167205.

U.S. Department of Health \& Human Services (2018): ANNUAL UPDATE OF THE HHS POVERTY GUIDELINES. (online) Available at: https://aspe.hhs.gov/legacy-page/2005-federal-register-notice-povertyguidelines-146721 Accessed 27 Feb. 2018.

United States Patent Application (2018): SOCIOECONOMIC GROUP CLASSIFICATION BASED ON USER FEATURES. (online) Available at: http://appft.uspto.gov/netacgi/nph-

Parser?Sect $1=$ PTO1 $\&$ Sect $2=$ HITOFF $\& d=P G 01 \& \mathrm{p}=1 \& \mathrm{u}=\% 2$ Fnetahtml\%2FPTO $\% 2 F s r c h n u m . h t m l \& \mathrm{r}=1 \& \mathrm{f}=$ G\&l=50\&s1=\%2220180032883\%22.PGNR.\&OS=DN/20180032883\&RS=DN/20180032883 Accessed 27 Feb. 2018.

Wadhwa, V., Holly, K., Aggarwal, R. and Salkever, A. (2009): Anatomy of an Entrepreneur: Family Background and Motivation. SSRN Electronic Journal. (online) Available at:

http://www.kauffman.org/ /media/kauffman_org/research\%20reports\%20and\%20covers/2009/07/anatomy_of _entre_071309_final.pdf Accessed 27 Feb. 2018.

Walsh, K., Jennings, M. and Stoker, L. (2004): The Effects of Social Class Identification on Participatory Orientations Towards Government. British Journal of Political Science, 34[3], pp.469-495. (online) Available at: https://www.jstor.org/stable/4092330?seq=1\#page_scan_tab_contents Accessed 27 Feb. 2018.

Wright, E. (2000): Class counts. Cambridge [u.a.]: Cambridge Univ. Press [u.a.]. (online) Available at: https://www.ssc.wisc.edu/ wright/Published\%20writing/Class-Counts-chapter-1.pdf Accessed 27 Feb. 2018.

Wright, E. (2007): Approaches to class analysis. Cambridge [u.a.]: Cambridge Univ. Press. ISBN 0521603811

Xie, Y., Zhou, X. (2014): Income inequality in today's China. Proceedings of the National Academy of Sciences, 111(19), 6928-6933.

Xinhuanet.com (2018): China Focus: China raises pensions amid pressure from slowing economy, aging population - Xinhua | English.news.cn. (online) Available at: http://www.xinhuanet.com/english/201704/14/c_136209480.htm Accessed 27 Feb. 2018. 